\title{
An extended Cyberhunts strategy: Learner centred learning-by-design
}

\author{
André du Plessis and Paul Webb \\ Nelson Mandela Metropolitan University
}

\begin{abstract}
The aim of this paper is to introduce to the education community to a newly developed 'Learner Centred Learning-By-Designing Extended Cyberhunts' (LCLBDEC) strategy for teaching and learning in schools. The main focus of the strategy is to enable learners to become designers of an educational tool which assists them to learn during the design process, and also can be used by other learners or students to get a better understanding of a topic. It is suggested that the strategy assists learners to clarify misconceptions that they might have and that it allows them to address aspects in the curriculum when there is not enough time to do so in class. During the initial stages of the strategy, learners are exposed to teacher designed Cyberhunts, a strategy that can be used to introduce learning by design to novices. As the learners become more computer literate, they become the designers instead of the teacher. Learners search for information online on a topic or theme and then are not only required to create questions on as many different cognitive levels as possible, but also to compose a complementing memorandum. The strategy is not meant to be in competition with WebQuests and other similar approaches, but should be seen as an additional information communication and technology (ICT) strategy to complement those that already exist.
\end{abstract}

\section{Introduction}

The Australasian Journal of Educational Technology has published various articles regarding Web 2.0 technologies (Cochrane \& Bateman, 2010; Gray, Thompson, Sheard, Clerehan \& Hamilton, 2010; McLoughlin \& Lee, 2010; Scutter, Stupans, Sawyer \& King, 2010). These studies suggest that researchers in the Zanzar region, and their South-East Asian counterparts, have pioneered a number of new and innovative strategies including the use of podcasts, MP3-capable devices, social software, personal digital assistants (PDAs), etc. Their findings suggest a new wave of online behaviour, distributed collaboration, and social interaction.

However, in South Africa (Department of Education, 2004; Howie, Muller \& Paterson, 2005; Mlitwa \& Nonyana, 2008), Africa (Africa Partnership Forum, 2008) and many regions of southern Asia (SEAMEO, 2010), schools may have great difficulty in providing children with access to computer hardware, let alone to the connectivity, hardware and software required for many of the teaching and learning strategies that have been developed. There seems to be a paucity of information for teachers on 'how to', i.e. strategies to provide clear guidelines for ICT implementation (HodgkinsonWilliams, 2005). As such, this paper attempts to meet the challenge half-way by discussing the design and fruitfulness of a strategy that can be used offline as well as online to promote a social/participatory pedagogy where computers are available (but 
not necessarily connected to the Internet). In the process learners become the designers of artefacts which could enhance their own learning, as well as that of their peers.

Students (and learners) not only seem to have high expectations of how they should learn, but they also demand that technology should play an integral part in their learning (Conole \& Creanor, 2007), which suggests that learning should become more self-regulated (McLoughlin \& Lee, 2010). McLoughlin and Lee (2010) refer to Stubbé and Theunissen (2008) in stating that learning activities should have knowledge creation, comprehension and higher order learning at its core through the use of selfmonitoring, reflection, testing, questioning and student self-evaluation. For this to happen, teachers will have to change their traditional teaching role from delivering pre-packaged facts to a facilitating role which is characterised by a social and participatory pedagogy (McLoughlin \& Lee, 2010). In turn, several authors have proposed that in order to achieve such a social/participatory pedagogy students (or learners) should become the designers of artefacts which enhance their own learning and which can be used by their peers (Cameron \& Gotlieb, 2007; Jonasson, 2000; Harel \& Papert, 1991; Kafai \& Resnick, 1996; Kimber \& Wyatt-Smith, 2006; Perkins, 1986). Technology can provide the information resource tools, authoring tools and knowledge construction tools that are required for this process (Perkins, 1986) which aims at developing a number of cognitive dimensions (Ainley, Banks \& Fleming, 2002).

Traditional Cyberhunts are introductory online activities where learners use the Internet as a tool to find answers to teacher defined questions on a predetermined theme or topic (Rechtfertig, 2002). The teacher provides a hyperlink which the learner explores and by exploring the material they attempt to answer the question. Teachers may use Cyberhunts as an introduction to a theme in a pre-activity, as a review for an upcoming test or as another form of authentic assessment (Slayden, 2000). In a similar vein, WebQuests are "an inquiry based activity in which all or most of the resources are Internet-based" (Dodge, 1997, p. 1). They have an introductory section, a 'do-able' task section, an information resources section, a description of the process to be followed section, a guidance section, an evaluation or assessment section, and a conclusion section (Dodge, 1997; Schweizer \& Kossow, 2007). WebQuests are largely teacher designed (Kurt, 2009).

However, as our purpose was to develop a strategy in which learners are the designers, the underpinning principles of WebQuests and traditional Cyberhunts had to be extended and broadened. In addition, the intervention had to afford learners with opportunities to specifically address different cognitive levels (knowledge, comprehension, application, analysis, synthesis and evaluation) when phrasing questions on the topic that they explored and when creating a possible memorandum during the design process. In order for teachers to address the different cognitive levels indicated above, they would have to be well informed about the key verbs associated with each cognitive level. It is therefore suggested that they are provided with a table that indicates the various cognitive levels (Table 1) and the associated verbs with each level, as well as possible sample questions.

\section{Theoretical perspectives underpinning the strategy}

Epistemologically, we argue that the strategy is underpinned by constructivist principles, constructionism, collaboration and motivation (see Wisnudel, 1994; and McGrath, Cumaranatunge, Chen, Broce \& Wright, 1997), and that there is the 
possibility of developing cognitive domains when learners become designers of an artefact or product (Ainley et al., 2002, Perkins, 1986; Jonassen, 2000). In order for this to happen the products that are produced must be useful to learners and learning should be 'meaningful', i.e. learning that is characterised by attributes such as being active, intentional, constructive, cooperative and authentic (Jonassen, Howland, Moore, Mara \& Crismon, 2008). Collaboration plays an important role within social constructivist learning and has a significant impact during the process of design in terms of offering possibilities to enhance cognitive and social skills (Wisnudel, 1994, Chen, 1999; McMahon, 1997). Constructionism is an extension of constructivism, i.e. it takes place when the emphasis is on building or creating something where not only the product is important, but the also the process (Stager, 2005; Ackerman, 2001; Harel \& Papert, 1991).

Treating knowledge as design has the potential to move teacher beliefs away from 'knowledge as information' and the 'knowledge-as-transmission-model' (Jonassen, 2000; Jonassen et al., 2008; Harel \& Papert, 1991; Kafai \& Resnick, 1996; Kimber \& Wyatt-Smith, 2006). The reasoning behind this claim is that the design act promotes active and creative use of knowledge by the learners. When they design, they may be required to make use of diverse intelligences such as their artistic, logical, linguistic, musical, as well as other talents, to accomplish the design task (Ivers \& Baron, 2006), and Kimber \& Wyatt-Smith (2006), Jonassen (2000) and Jonassen et al. (2008) all suggest that learners learn more when they become designers.

Another underpinning perspective is that motivation plays an important role during authentic artefact construction (Du Plessis, 2004; Wisnudel, 1994), especially when working [or learning] becomes play (Webster, Trevino \& Ryan, 1993). Motivational theory presented in the seminal works of Keller (1983) and Malone and Lepper (1987) highlight factors that can enhance motivation. We believe these factors should be planned for and embedded in design learning activities, i.e. that they should relate to (1) curiosity, fun and attention, (2) challenges, competence and relevance, (3) control, choice and voice, (4) fantasy and novelty, (5) collaboration and (6) recognition. We are also of the opinion that when learners are actively involved in the design process and successfully complete their artefact and experience recognition by others, they perceive the task as 'fun' and can become highly motivated.

We believe that, by using the Learner Centred Learning-by-Design Extended Cyberhunts (LCLBDEC) strategy described in this paper, learning becomes meaningful as it is the learners who actively construct meaning through designing their Cyberhunts. In addition, their learning becomes intentional as they set goals for themselves in reflective journals. Learners are required to share ideas and edit collectively as they design Cyberhunts on authentic curricular topics. They are expected to make meaning through searching for information, posing questions on different cognitive levels, and reflecting in their journals on pre-determined questions. These activities enable the constructive dimension of meaningful learning (Gagnon \& Collay, 2006; Jonassen et al., 2008).

When computers are used as authoring and knowledge construction tools using activities that address both knowledge and cognitive processing dimensions, learners learn 'with' the computer rather than 'from' the computer (Jonassen, 2000; Jonassen et al., 2008). The knowledge dimension refers to factual knowledge, conceptual knowledge, procedural knowledge and metacognitive knowledge. Factual knowledge 
refers to basic information. Conceptual knowledge refers to the way in which basic information connects to other more complex information, for example theories and classifications. Procedural knowledge refers to methods or ways on how to do something (as well as knowledge of the criteria used for this). Metacognitive knowledge (or thinking about one's own thinking or doing) refers to self-awareness about one's learning (Ainley et al., 2002).

The cognitive dimension includes remembering, understanding, applying, analysing, evaluating and creating (Ainley et al., 2002). Remembering refers to recognition and recall. Understanding relates to constructing meaning (for example by providing a summary, comparing or classifying something), applying relates to carrying out or using a procedure. Analysing refers to investigating something. Evaluating refers to assessing a product, process or something else based on criteria. Creating could imply producing a product, including the planning or designing of a product or to a procedure (Ainley et al., 2002). All of these dimensions are considered in the process of design.

In order to develop the LCLBDEC approach, several sources related to design were consulted. Lehrer (1993) states that there are four phases in the design process, including planning, transforming and translating, and evaluating and revising. Allessi and Trollip (2002) note that in real world contexts, designers follow a procedure of planning, designing and developing things. They contend that evaluation plays an important role during the development process. Liu (2003) cites a similar procedure which begins with planning and then leads to design, production and evaluation and revising. Thus Liu (2003) has separated the evaluation and revising stage from the production phase, which is sub-assumed in the Allessi and Trollip framework under the development stage/phase. In turn, Ivers and Baron (2006) proposed a 'DDDE' design framework, viz. decide, design, develop and evaluate.

In the LCLBDEC framework discussed in this paper a high premium is placed on planning, thinking, on the different cognitive levels, designing, developing, presenting, assessing and revising. In addition, journal writing and reflection are also viewed as important. Learners are encouraged to complete journal entries on predetermined questions on their journal sheets to articulate their thinking, their needs and the learning that occurs. These journals are completed during each contact period and provide the teacher with an overview of the learners' experiences each time.

\section{The learner centred learning-by-design extended Cyberhunt (LCLBDEC) strategy}

The Learner Centred Learning-By-Design Extended Cyberhunts (LCLBDEC) framework (Figure 1) suggested in this paper was designed using the ideas of Alessi and Trollip (2002), Ivers and Baron (2006); Lehrer (1992), Du Plessis (2004), and Morrison and Lowther (2002). The strategy presented is a form of project-based learning (PBL). Project-based learning is a learner-centred approach in which learners are expected to exercise autonomy over what they learn (Grant, 2002; Wong, Quek, Divaharan, Liu, Peer \& Williams, 2006). Both the teacher and/or learners can decide on the question, problem or topic to be investigated and the creation of a product or artefact is given great importance and seen as a representation of the learner's thinking (Blumenfeld, Soloway, Marx, Krajcik, Guzdial \& Palincsar, 1991; Wong et al., 2006). 
Lamb, Smith and Johnson (1997) provide an interesting model comprising eight steps that teachers can use within a project-based learning context or learning space. These eight steps are:

- Watching (identifying potential projects to explore in their community);

- Wondering (brainstorming possible ideas to investigate);

- Webbing (locate or searching for information);

- Wiggling (evaluate the appropriateness and quality of the information found);

- Weaving (synthesising information);

- Wrapping (packaging ideas);

- Waving (sharing and publicising their ideas); and

- Wishing (reflecting on the project and the process) (Lamb, Smith \& Johnson, 1997).

In order to show how the 'learner designed' LCLBDEC framework relates to the PBL steps, the steps of Lamb, Smith and Johnson (1997) have been adapted to indicate that 'learner designed Cyberhunts' can also be linked to the eights Ws used in a PBL framework or model, if it is extended to eleven Ws. The rationale was not to show that LCLBDEC framework follows similar design steps as PBL, but that the LCLBDEC design process not only addresses similar aspects, but also extends it. It is important to note that the main difference between the LCLBDEC framework and PBL is the fact that it is the learners who compose questions on different cognitive levels, they provide the hyperlinks and they also compile a memorandum. However, it is also important to note that the learner-designed Cyberhunts are designed by learners for other learners or even for teachers to use. Teachers could thus decide to implement the LCLBDEC strategy in order that learners-as-designers have an opportunity to explore a topic, to enrich their knowledge, to ameliorate understanding of a topic(s) with which they or their peers struggle and/or to address an aspect in the curriculum for which they do not have time to address during normal class time.

The adapted twelve Ws related to Cyberhunts in the LCLBDEC framework based upon Lamb, Smith and Johnson (1997) are:

- Wowing: Teacher explanation of outcomes, assessment, results presentation and the identification of a potential topic that could be useful to explore. The rationale for selecting this specific topic could be to assist learners who are struggling with a topic or to select a section in the curriculum that the teacher cannot cover as a result of time constraints. Another possibility could be to select a topic or aspects that can be probed in a much deeper level for enrichment or deeper learning purposes. This also implies decision-making.

- Wanting: Learners plan by setting goals in their journals on pre-defined questions that they want to achieve.

- Wondering: Learners brainstorm or think about possible sub-themes or sub-sections to explore, define keywords or key phrases to assist with their searching as well as possible questions that they would like to compose, i.e. what information they think is required to be explored.

- Webbing: Learners search for information. They read, scan and skim and bookmark relevant websites or copy the hyperlinks or URLs to their design software. They also make summaries of any information or proposed questions. 
- Wiggling: Learners evaluate the quality of the information found. It also implies categorising, connecting, linking information and posing questions on the different cognitive levels to address or to develop the different cognitive levels. This is also the most cognitive challenging aspect in the design process. It is important that the verbs associated with the different cognitive levels are provided to the learners.

- Weaving: Learners design and structure their 'learner created' Cyberhunts on the computer. This also includes typing their questions and indicating the different cognitive levels of question within brackets. In addition, the learners complete the memorandum and add or rephrase any questions, if necessary - the main focus section of the LCLBDEC.

- Wrapping-up: Learners make their design or layout attractive to their users, write the necessary instructions, test whether all the hyperlinks are working and ascertain whether different levels of questions have been appropriately addressed.

- Waving, Wmail and Wupload: The learners and teacher invite other learners to use the completed 'learner designed' artefact after they have uploaded or emailed their completed designs to their peers or teacher.

- Wising: The learners reflect on the design process with a view to articulating in their journals what to do differently in future, thus sharing their wise thoughts.

Questions in their journals could refer to what they found easy, difficult, problems experienced, name the skills that they think they have learned, what they enjoyed, whether problems were resolved or not and by whom they were resolved, and any other comments that they may want to make. The learners share their 'wise' experiences with rest of class and the teacher reads their journals after school and reflects on the session with a view to assisting learners during the next session.

The points above suggest that the LCLBDEC framework does contain certain elements associated with a WebQuest, such as creating a product and finding information, but that they also contain distinguishing characteristics, namely that the final products are designed by learners in order that other learners can use their created artefacts. In addition, the formulation of questions on different cognitive levels by the 'learners-asdesigners' is unique to the LCLBDEC framework.

With reference to classroom implementation, the teacher or facilitator cannot simply assume that learners have the necessary reading and comprehensions skills, or the strategies required to implement strategies. They are key factors in the design process and have to be taught. Likewise, keyword generation, decision making skills (e.g. topic selection and ascertaining the truthfulness of information), as well as Internet search skills are skills that have to be learned.

What makes the LCLBDEC process comprehensive is the fact that it includes not only the design phases, but also the classroom implementation phase in detail, including what should happen in the classroom (indicated in Figure 1 under Phase 2). However, it could be useful that the teacher design the first Cyberhunt(s), in order that the learners can practically engage and experience the Cyberhunt strategy and that they can visualise the design. However, if the learners are in an advanced ICT stage, the idea could be explained (they could even visit the website that explains the process available at http:/ / www.nmmu.ac.za/cyberhunt/) and the learners could start then with Phase 2, as indicated in Stage 8 in Figure 1. 


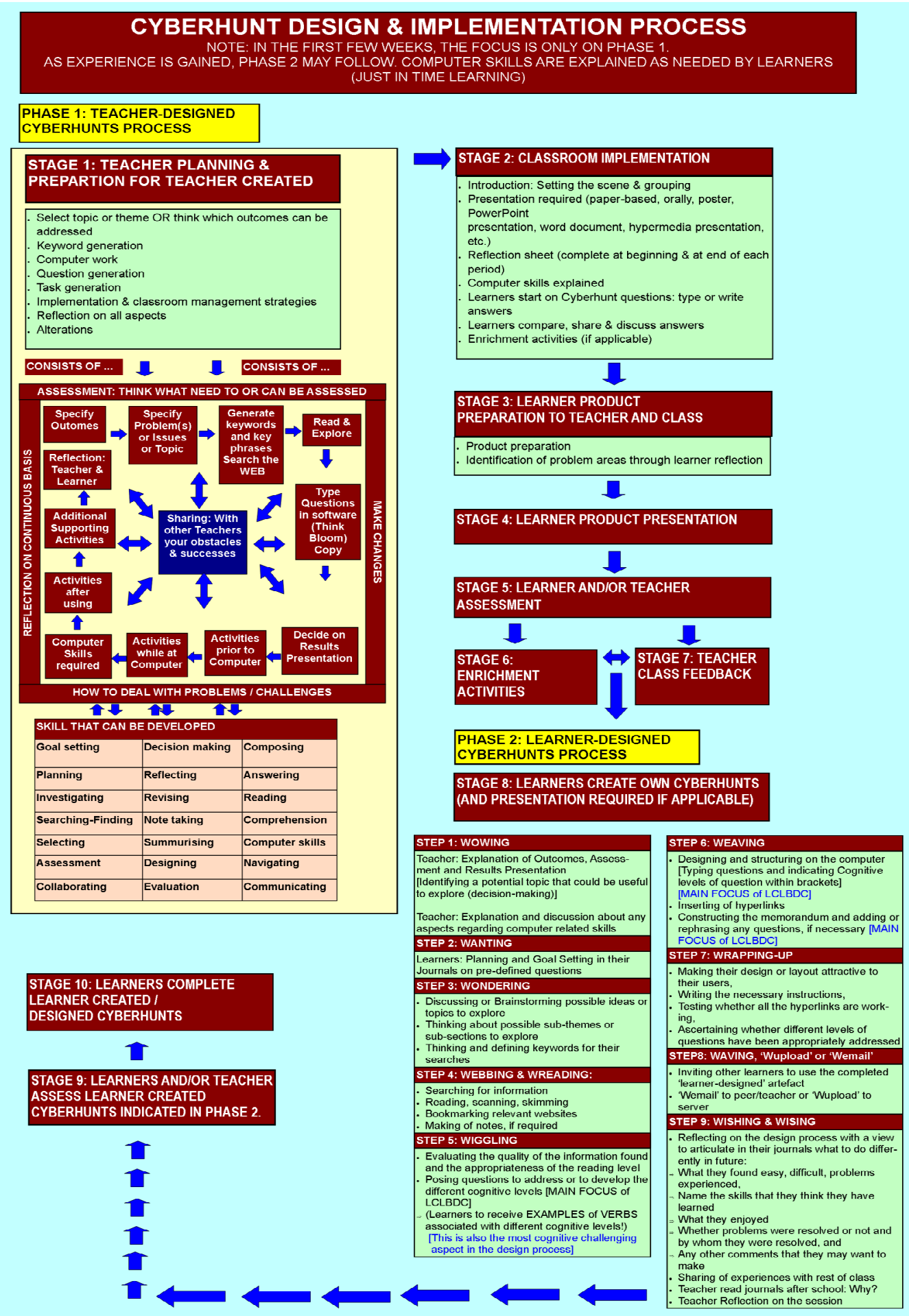

Figure 1: The Extended Cyberhunt design and implementation process 
The design for traditional teacher-designed Cyberhunts comprises seven stages (see Figure 1). The LCLBDEC process consists of one phase, comprising nine steps or eleven Ws and three stages [Stage 8 to 10] (see Figure 1). The process for the design of traditional teacher-designed Cyberhunts, as well as the 'learner designed' Cyberhunts (LCLBDEC) process and implementation, are both presented in Figure 1. Each of the phases and stages are unpacked below.

\section{Phase 1}

- Stage 1: Teacher preparation for teacher created Cyberhunt(s).

- Stage 2: Classroom implementation.

- Stage 3: Learner product preparation feedback to teacher and/or the whole class (if required) at the end of the session.

- Stage 4: Learner product presentation.

- Stage 5: Learner and/or teacher assessment.

- Stage 6: Enrichment activities.

- Stage 7: Teacher class feedback.

\section{Phase 2}

- Stage 8: Learners create own Cyberhunts (and presentation required if applicable) by using the same processes as used in Stage 1 [See Phase 2 in Figure 1] namely: Wowing, Wanting, Wondering, Webbing, Wiggling, Weaving, Wrapping up, Waving, Wmail and Wupload, as well as Wising.

Stages 1 to 7 provide an overview of the process to be followed for 'teacher-designed' Cyberhunts. Stage 1, the planning and preparation stage, is the most important stage, as it sets the scene for the rest of the stages to follow. Stage 1 encompasses the following:

- The thinking that entails the specification of the learning outcomes;

- The identification of the topic, theme or problem;

- The generation of keywords and key phrases;

- Searching for, exploring and reading of the web results;

- Question generation on the different cognitive levels related to Bloom's Taxonomy according to Anderson et al (2000);

- Hyperlinking;

- The designing of the Cyberhunt in a suitable software application;

- Deciding upon the results presentation;

- Deciding upon any activities prior to using the computer, if required;

- Deciding upon activities while busy on the computers;

- Determining the required computer skills;

- Deciding upon activities after using the computer;

- Deciding upon any other additional non-computer related activities; and

- Preparing learner reflection sheets.

Stage 2 is the classroom implementation stage, comprising:

- Introduction: Setting the scene and grouping;

- Presentation required (paper based, orally, poster, PowerPoint presentation, Word document, hypermedia presentation, etc.);

- Reflection sheet (complete at beginning and end of each period); 
- Computer skills are explained;

- Learners start on Cyberhunt questions: type or write answers;

- Learners compare, share and discuss answers;

- Enrichment activities (if applicable).

Stage 3 is the learner product preparation stage. During this stage, the learner(s) can present individual or group presentations to the teacher and/or to the class either on paper, poster or a PowerPoint presentation. The learners could also be required to use reflective journal sheets to set goals for their product preparation, if they for example use PowerPoint as a presentation tool, they could be asked to identify the problem areas and write these on their reflective journal sheets. It is also possible that the teacher and the learners can decide jointly what types of presentation are required.

In Stage 4, the learners present their created products to the teacher, to their group and / or to the whole class; depending on what was decided upon during Stage 1 by the teacher. Stage 5 is assessment stage. During the assessment stage, the learners are assessed by means of a rubric or checklist, either by their teacher, by their peers or by both the teacher and their peers. The teacher could also have planned an enrichment activity or activities related to the topic, which may follow after Stage 5, hence Stage 6 is called the enrichment activity phase. During Stage 7, the teacher provides feedback to the class regarding their assessment and on any other aspects that the teacher views as necessary.

As the learners become more competent and confident to complete the teacher-created Cyberhunts and to present their findings, the teacher can proceed to the next phase, i.e. Phase 2 indicated in Figure 1 which refers to 'learner-designed' Cyberhunts. This phase is on a higher level as it requires the learners to become the designers of their own individual or collaborative Cyberhunts on given topics. During this phase with its different stages indicated below Phase 2 in Figure 1, the learners plan in a similar manner as the teacher did during Stage 1 in Phase 1, as the learners have to engage with the aspects that have been indicated in Stage 1 . These phases are clearly indicated under Phase 2 in Figure 1. The learners follow the proposed classroom implementation procedure, as indicated under Stage 8 in Figure 1 as indicated by the thirteen Ws. The timeframe to have a completed 'learner-designed' Cyberhunt artefact will depend on several factors, e.g. the learners ICT skills and access to ICT resources. Thus, the teacher could decide that it will be a 3 to 5 day project ( 1 to 2 hours per day) or a 3 to 5 week project.

The proposed procedure for classroom implementation of learner-designed Cyberhunts (LCLBDEC) comprises the following:

- The teacher explains the intended outcomes, assessment requirements and design requirements (3-5 minutes) [Phase 2: Step 1].

- The learners plan and set their goals for the session in their journals [Phase 2: Step 2].

- The learners plan and start with the design process (computer and/or pen and paper related activities, 40-60 minutes), namely [Phase 2: Steps 3 to 8]:

- Keyword/phrase generation;

- Search by using search engines;

- Select and / or bookmark relevant web sites;

- Evaluate information (scan, skim, read); 
- Make notes or summaries;

- Select and decide on the questions to be composed;

- Type the questions in their selected design software;

- Copy the hyperlink(s);

- Insert visual material (if required);

- Type the instructions;

- Save and test their product; and

- Upload to server if required.

- The learners complete their journals (5-8 minutes) at the end of the day's session pertaining to predefined questions, for example what they found easy, what they found difficult, the problems experienced, whether the problems were resolved or not, by whom they were resolved, and any other comments that they may want to make. The teacher may also decide to complete a journal with similar questions in order to reflect upon what he/she has noticed during the session [Phase 2: Step 9].

- The learners share their recorded journal experiences with their teacher and one another (5-8 minutes). Alternatively, the teacher may decide that the learners are not going to share their experiences at the end of every session, but only during some of the sessions. The teacher may then decide to read the learners' responses in their journals alone at an appropriate time. The learner reflection assists with further planning, as it provides the teacher with insight into the learners' needs [Phase 2: Step 9].

Stage 9, the stage that follows Stage 8 with its various steps, is an optional step that provides extended opportunities to the learners or teacher to assess the learner created Cyberhunts that have been created over a period of time. During this stage, suggestions can be made and the learners are afforded with opportunities to make additional suggested changes. After the changes have been made, the learners save their designs for the second time and can upload them again to a space indicated by the teacher or email to the teacher. The final stage is Stage 10. During this stage the learners can complete one another's or the collaborative created Cyberhunts of other groups. The teacher has also the option that learners from other classes or other grades could use the learner-designed Cyberhunts as a learning tools.

It is important to note that the period of time allocated to the learner-design process of Cyberhunts will depend on the level of the learners' computer and Internet skills, their design skills, their searching and finding appropriate information skills, and their question creation skills.

Another important facilitating aspect of the LCLBDEC strategy is that the designer is not limited to the use of a word processor such as Microsoft Word or a web authoring software tool such as FrontPage. Virtually any software can be used, even presentation software, for example Microsoft PowerPoint. The only prerequisite is that the software or online tool should have a hyperlink option. If Internet access is not available, Microsoft Encarta or any other similar CD or DVD based encyclopaedia can be substituted, as an offline resource to be used in a similar manner. The only difference will be that hyperlinks cannot be provided.

The extended Cyberhunt presented in Figure 2 has been designed in PowerPoint. However, the student did not indicate the cognitive level within brackets. 


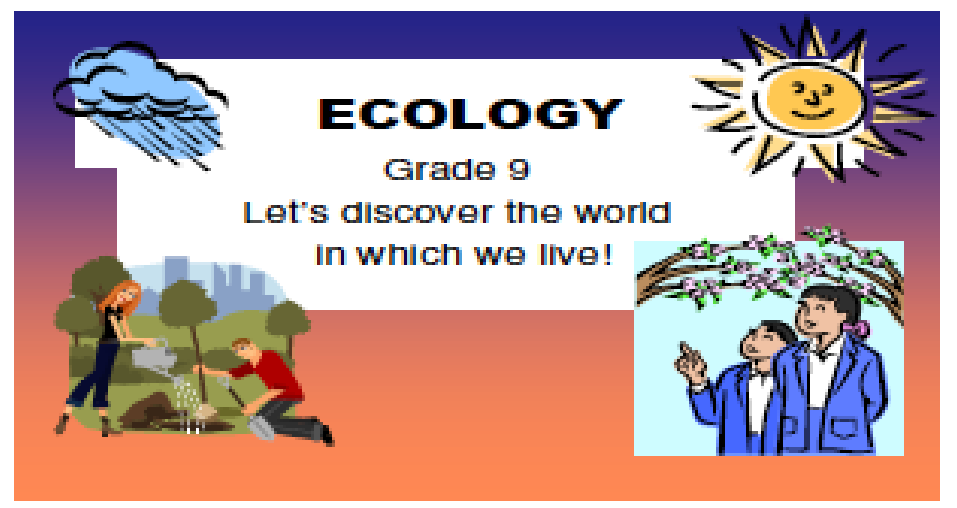

\section{Introduction to Ecology}

Check out the website Kids Do Ecology and its related links and after exploring, answer the questions that follow...

http://www.nceas.ucsb.edu/nceasweb/lids/ecologvilindex.html

- Define the term ecology.

- Name three jobs you could do after becoming an Ecologist

- Why is Ecology important?

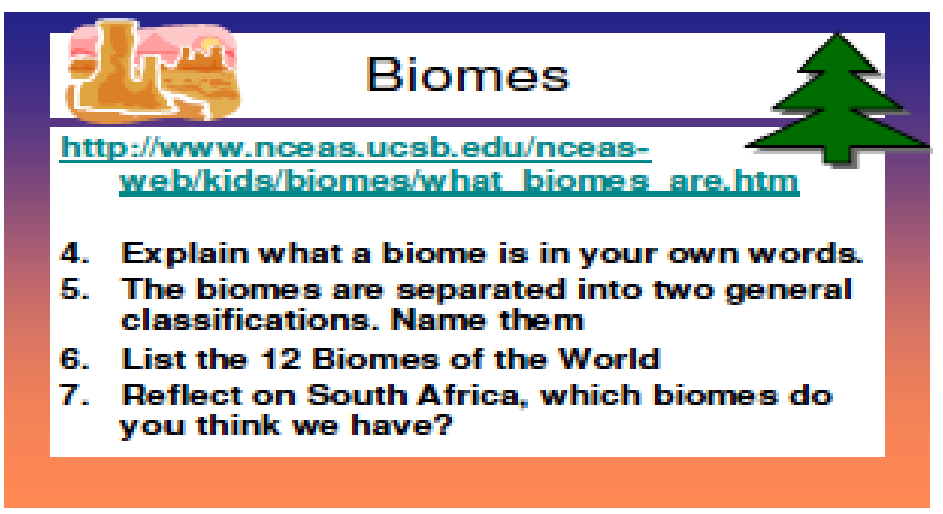

Figure 2: Example of an extended Cyberhunt in PowerPoint

In another example of a student designed Cyberhunt in Microsoft Word, portrayed by Figure 3, the student has indicated the cognitive level of the each question within brackets. 


\section{A VISIT TO ADDO ELEPHANT PARK}

Answer the questions on your printed worksheets. Click on the blue links to go to a website which has the information you need to answer the questions listed below it.

What to see and do in Addo

$\underline{\text { http://www.nature-reserve.co.za/cape-eastern-addo-elephant-park. html }}$

1. (Know) How many elephants are there in the Addo Elephant Park?

2. (Know) How far away from Port Elizabeth is the Addo Elephant Park?

3. (Know) Name three other kinds of large animals you could expect to see in Addo.

4. (Comp) What is another name for a suricate? Describe one in a sentence.

5. (Comp) What do you think is the main thing visitors to Addo, do?

6. (Comp) What other activities are there? (Name at least 3).

Accommodation at Addo $\quad$ http://www.sanparks.org/parks/addo/

7. (Know) What are the main types of different accommodation at Addo? Name at least five types.

8. (Appl) How many safari tents are available for the night of 1 September 2006 ?

9. (Know) How many people can sleep in each tent?

10. (Comp) Describe a safari tent in your own words (Hint: find some pictures).

11. (Appl) How much would it cost for a family of 2 adults and 2 children to share a Forest Cabin on the night of 1 September 2008 ?

12. (Comp) Which number would you phone to book your reservation?

Figure 3: Example of an extended Cyberhunt in Microsoft Word

\section{Knowledge and cognitive dimensions}

As noted earlier, comprehension and higher order learning can be addressed through reflection, questioning, self-evaluation and self-regulation (McLoughlin \& Lee, 2010), and that Ainley et al. (2002) state that ICTs should be used in authoring and knowledge construction mode. We also suggest that by using the LCLBDEC strategy, teachers can make it possible for learners to engage in various knowledge and cognitive dimensions. Such engagement can be through composing and answering questions on different cognitive levels (knowledge, comprehension, application, analysis, synthesis and evaluation) by the learners as designers.

At the same time, we are of the opinion that the LCLBDEC strategy has the potential to address the 'self-regulated' dimensions of learning, for example metacognition, planning, monitoring, and evaluating progress. Metacognition is addressed when the learners reflect in their journals and when they think about the correctness of their answers while designing a memorandum for their Cyberhunt (or about the correctness of their answers when completing someone else's Cyberhunt). Planning, monitoring and evaluation are aspects that are constantly addressed during Stages 8 and 9 of the 
'LCLBDEC Framework'. The relationships between types of knowledge and the cognitive dimensions of the process are illustrated in Table 1.

Table 1: Knowledge and cognitive dimensions of the LCLBDEC when incorporating reflective journal writing

\begin{tabular}{|c|c|c|c|c|}
\hline \multicolumn{5}{|c|}{ Types of knowledge } \\
\hline $\begin{array}{l}\text { Cognitive } \\
\text { processes }\end{array}$ & $\begin{array}{l}\text { Factual (basic } \\
\text { information) }\end{array}$ & $\begin{array}{l}\text { Conceptual (how } \\
\text { basic information } \\
\text { connects) }\end{array}$ & $\begin{array}{l}\text { Procedural (ways } \\
\text { on how to do } \\
\text { something as well } \\
\text { as knowledge of } \\
\text { the criteria used) }\end{array}$ & $\begin{array}{l}\text { Metacognitive } \\
\text { (thinking about } \\
\text { one's own } \\
\text { thinking or } \\
\text { progress) }\end{array}$ \\
\hline $\begin{array}{l}\text { Remembering } \\
\text { (recall) }\end{array}$ & $\begin{array}{l}\text { Learners provide } \\
\text { answers to factual } \\
\text { level questions in } \\
\text { the Cyberhunt. }\end{array}$ & & & \\
\hline $\begin{array}{l}\text { Understanding } \\
\text { (providing a sum- } \\
\text { mary, comparing } \\
\text { or classifying } \\
\text { something) }\end{array}$ & & $\begin{array}{l}\text { Learners provide } \\
\text { answers to } \\
\text { understanding } \\
\text { level questions in } \\
\text { the Cyberhunt. }\end{array}$ & & \\
\hline $\begin{array}{l}\text { Applying } \\
\text { (applying or } \\
\text { carrying out a } \\
\text { procedure) }\end{array}$ & $\begin{array}{l}\text { Learners using } \\
\text { other learners' } \\
\text { created } \\
\text { Cyberhunts }\end{array}$ & & $\begin{array}{l}\text { Learners provide } \\
\text { answers to apply- } \\
\text { ing procedural } \\
\text { level questions in } \\
\text { the Cyberhunt. }\end{array}$ & \\
\hline $\begin{array}{l}\text { Analysing } \\
\text { (investigating } \\
\text { something) }\end{array}$ & & $\begin{array}{l}\text { Learners provide } \\
\text { answers to } \\
\text { analysing level } \\
\text { questions in the } \\
\text { Cyberhunt. }\end{array}$ & & $\begin{array}{l}\text { Reflection: Compl- } \\
\text { eting journals to } \\
\text { reflect on what } \\
\text { they have learned } \\
\text { (skills, knowledge, } \\
\text { procedures, etc.). }\end{array}$ \\
\hline $\begin{array}{l}\text { Evaluating } \\
\text { (assessing a } \\
\text { product, process } \\
\text { or something else } \\
\text { based on criteria) }\end{array}$ & $\begin{array}{l}\text { Learners assess } \\
\text { other learners' } \\
\text { answers or } \\
\text { presentations. }\end{array}$ & $\begin{array}{l}\text { Learners assess } \\
\text { other learners' } \\
\text { answers or } \\
\text { presentations. }\end{array}$ & $\begin{array}{l}\text { Learners assess } \\
\text { quality of the } \\
\text { designed Cyber- } \\
\text { hunt based upon a } \\
\text { checklist or rubric. } \\
\text { Learners assess } \\
\text { other learners' } \\
\text { answers or } \\
\text { presentations. }\end{array}$ & $\begin{array}{l}\text { Reflection: Compl- } \\
\text { eting journals to } \\
\text { reflect on their } \\
\text { own progress } \\
\text { based upon evalu- } \\
\text { ation issues, e.g. } \\
\text { which goals have } \\
\text { you reached? } \\
\text { Which were not } \\
\text { reached? Explain. }\end{array}$ \\
\hline $\begin{array}{l}\text { Creating } \\
\text { (producing a } \\
\text { product, planning } \\
\text { or designing a } \\
\text { product or } \\
\text { procedure) }\end{array}$ & & $\begin{array}{l}\text { Learners create } \\
\text { their own } \\
\text { Cyberhunts in a } \\
\text { group or as } \\
\text { individuals. }\end{array}$ & & $\begin{array}{l}\text { Learners reflect in } \\
\text { their journals on } \\
\text { how well they } \\
\text { have designed it } \\
\text { and what changes } \\
\text { they should make } \\
\text { the next time. }\end{array}$ \\
\hline
\end{tabular}

Thus the LCLBDEC has the potential to address important knowledge and cognitive dimensions when learners design their own Cyberhunts. Also, when other learners provide answers to the learner created questions on different cognitive levels, they become the users of the learner created artefacts. 


\section{Discussion and conclusion}

Research reports suggest that the design of artefacts by learners appears to provide better retention and comprehension of content materials (Beichner, 1994; Chen, 1999; Yildirim, 2005), greater higher order thinking skills (Chen, 1999; Liu, 2003), increased self-esteem and confidence (McGrath et al., 1997), ownership (Lehrer, 1993; Du Plessis, 2004; 2010), and greater awareness of audience (Liu, 2003; Du Plessis, 2004, 2010; Beichner, 1994). Other benefits of the design approach are commitment and enthusiasm (Beichner, 1994), improved motivation, interest and cooperation (Turner \& Dipinto, 1992; Lehrer, 1993; Turner \& Dipinto, 1997; Liu, 1998; Du Plessis, 2004), and internalisation of design skills (Liu \& Hsiao, 2002; Liu, 2003; Du Plessis, 2004). Other reports include increased knowledge organisation and elaboration (Chen, 1999), as well as greater depth of knowledge, new perspectives on organising and presenting (communication) of information as well as new insights into writing (Turner \& Dipinto, 1992). There are also possibilities of seeing knowledge in a fundamentally different way, developing critical standards for knowledge (Lehrer, Erikson \& Connell, 1994), and providing different ways of designing approaches and opportunities for meaningful reflection (Kafai, 1996).

In this article we have presented the LCLBDEC framework as a 'learning-as-design' strategy that has the potential to promote a social and participatory pedagogy when learners become the designers of artefacts. We argue that by using the LCLBDEC framework in a 'learning-as-design' context, in which learners search for information on specified topics and learners construct questions on different cognitive levels, has not only the potential "to generate thought" (Hokanson \& Hooper, 2000, p. 547), but also addresses various other aspects during the design-construction process. These aspects include providing opportunities for learners to develop project management skills, research skills, organisation and representation skills, presentation skills and reflection skills (Carver, Lehrer, Connell \& Erickson, 1992; Lehrer, 1993; Lehrer et al., 1994; Liu, 2003; Du Plessis, 2004, 2010) as a result of their involvement in the construction of their own or collaborative artefacts. Each of these skills include various sub-skills, for example research skills include reading, note taking, defining or creating keywords, validation of the quality of knowledge, and search skills.

If the preceding argument is accurate, using the strategy should generate and enhance thinking when learners compose questions and design their own Cyberhunts, i.e. when they move away from being passive consumers of knowledge to generators of knowledge. It should also allow both learners and teachers to learn more about a topic and/or to clarify misconceptions in their understanding. Consideration of the benefits recorded by many researchers, examining similar approaches (traditional Cyberhunts and WebQuests), and of the effects of the implementation of extended Cyberhunts (Du Plessis, 2010), suggest that there is a distinct possibility that the process may assist in meeting many of the outcomes of current curricula and could also enhance motivation, interest and collaboration among learners. In a forthcoming article we intend to provide quantitative and qualitative data to portray the perceptions of participating teachers related to the LCLBDEC framework.

\section{References}

Ackerman, E. (2001). Piaget's constructivism, Papert's constructionism: What's the difference? Paper presented at the 2001 Summer Institute, Mexico City. [viewed 12 Jan 2009, verified 13 Nov 2011] http:/ / learning.media.mit.edu/ content/publications/EA.Piaget $\% 20 \% 20$ Papert.pdf 
Africa Partnership Forum (2008). ICT in Africa: Boosting economic growth and poverty reduction. Prepared by Gerster Consulting under a mandate from the Africa Partnership Forum Support Unit for the 10th Meeting of the Africa Partnership Forum, Tokyo, 7-8 April 2008. http: / / www.oecd.org/ dataoecd /46/51/40314752.pdf

Ainley, J., Banks, D. \& Fleming, M. (2002). The influence of IT: Perspectives from five Australian schools. Journal of Computer Assisted Learning, 18(4), 395-404. http: / / dx.doi.org/10.1046/j.0266-4909.2002.00251.x

Alessi, S. M., \& Trollip, S. R. (2001). Multimedia for learning: Methods and development. Boston: Allyn and Bacon.

Anderson, L.W., Krathwohl, D. R., Airasian, P. W., Cruikshank, K. A., Mayer, R. E., Pintrich, P., Raths, J. \& Wittrock, M. (2000). A taxonomy for learning, teaching, and assessing: A revision of Bloom's Taxonomy of educational objectives, abridged edition. Allyn \& Bacon.

Beichner, R. J. (1994). Multimedia editing to promote science learning. Journal of Educational Multimedia and Hypermedia, 3(1), 55-70. [verified 13 Nov 2011] http: / / www.ncsu.edu/per/Articles/MultimediaEditing.pdf

Blumenfeld, P. C., Soloway, E., Marx, R. W., Krajcik, J. S., Guzdial, M. \& Palincsar, A. (1991). Motivating project-based learning: Sustaining the doing, supporting the learning. Educational Psychologist, 26(3), 369-398.

Carver, S.M., Lehrer, R., Connell, T. \& Erickson, J. (1992). Learning by hypermedia design: Issues of assessment and implementation. Educational Psychologist, 27(3), 385-404. http: / / dx.doi.org/10.1207/s15326985ep2703_7

Chen, H. (1999). A case study of knowledge construction and knowledge representation in high school students' design of hypermedia documents. Unpublished Doctor of Philosophy. Department of Foundations and Adult Education College of Education, Kansas State University, Manhattan, Kansas. [viewed 26 May 2002 at http:/ / www2.educ.ksu.edu/ Faculty / McGrathD/Spring01/Chen/index.html, not found 13 Nov 2011]

Cochrane, T. \& Bateman, R. (2010). Smartphones give you wings: Pedagogical affordances of mobile Web 2.0. Australasian Journal of Educational Technology, 26(1), 1-14. http: / / www.ascilite.org.au/ajet/ajet26/cochrane.html

Conole, G. \& Creanor, L. (2007). In their own words: Exploring the learner's perspective on e-learning. London: JISC. [viewed 17 Oct 2009].

http: / / www.jisc.ac.uk/media/ documents/programmes/elearningpedagogy/iowfinal.pdf

Department of Education [DOE] (2004). Transforming learning and teaching through information and communication technologies. (Draft White Paper on e-Education, Government Gazette, 246 August 2004): Gazetted Version. [viewed 25 Feb 2008, verified 13 Nov 2011] http: / / www.polity.org.za/attachment.php?aa_id=1528

Dodge, B. (1997). Some thoughts about WebQuests. [viewed 18 Jun 2007, verified 13 Nov 2011] http: / / webquest.sdsu.edu / about_webquests.html

Du Plessis, A. (2004). Learners' perceptions of creating a collaborative hypermedia product: An exploratory case study at Mount Pleasant Primary School. Unpublished MEd Thesis, Rhodes University: South Africa. http:/ / www.ecdoe.gov.za/research/publications_179.htm

Du Plessis, A. (2010). The introduction of cyberhunts as a teaching and learning strategy to guide teachers towards the integration of computer technology in schools. Unpublished PhD Thesis, Nelson Mandela Metropolitan University: South Africa. [verified 13 Nov 2011; 8.5 MB] http: / / www.nmmu.ac.za/ documents / theses / Thesis $\% 20$ with\%20Appendices.pdf 
Gagnon, G.W. \& Collay, M. (2006). Constructivist learning design: Key questions for teaching to standards. Thousand Oaks, California: Corwin Press.

Grant, M. M. (2002). Getting a grip on project-based learning: Theory, cases and recommendations. Meridian: A Middle School Computer Technologies Journal, 5(1). http: / / www.ncsu.edu/ meridian/win2002/514/3.html

Gray, K., Thompson, C., Sheard, J., Clerehan, R. \& Hamilton, M. (2010). Students as Web 2.0 authors: Implications for assessment design and conduct. Australasian Journal of Educational Technology, 26(1), 105-122. http:/ / www.ascilite.org.au/ajet/ajet26/gray.html

Harel, I. \& Papert, S. (Eds.) (1991). Software design as a learning environment. In I. Harel \& S. Papert (Eds.), Constructionism: Research reports and essays 1985-1990 by the Epistemology and Learning Research Group (pp. 41-84). New Jersey: Ablex.

Hodgkinson-Williams, C. (2005). Dust on the keyboards: Policy gaps in the integration of ICT into the South African curriculum. Proceedings of the 8th IFIP World Conference on Computers in Education, 4-7 July. Stellenbosch: University of Stellenbosch.

Hokanson, B. \& Hooper, S. (2000). Computers as cognitive media: Examining the potential of computers in education. Computers in Human Behavior, 16(5), 537-552. http: / / dx.doi.org/10.1016/S0747-5632(00)00016-9

Howie, S. J., Muller, A. \& Paterson, A. (2005). Information and communication technologies in South African secondary schools. Cape Town: SITES, HSRC Press.

Ivers, K. S. \& Baron, A. E. (2006). Multimedia projects in education: Designing, producing and assessing. Westport, Conn: Libraries Unlimited.

Jonassen, D. H. (2000). Computers as mindtools for Schools: Engaging critical thinking. Upper Saddle River, New Jersey: Merrill, Prentice Hall.

Jonassen, D. H., Howland, J., Moore, J., Marra, R. M. \& Crismond, D. (2008). Meaningful learning with technology. New Jersey: Merrill, Prentice Hall.

Kafai, Y. B. \& Resnick, M. (1996). Introduction. In Y. Kafai \& M. Resnick (Eds.), Constructionism in practice: Designing, thinking and learning in a digital world (pp. 1-8). Mahway, NJ: Lawrence Erlbaum Associates.

Keller, J. M. (1983). Motivational design of instruction. In C. M. Reigeluth (Ed.), Instructional design theories and models: An overview of their current status (pp. 383-434). Hillsdale, NJ: Erlbaum.

Kimber, K. \& Wyatt-Smith, C. (2006). Using and creating knowledge with new technologies: A case for students-as-designers. Learning, Media and Technology, 31(1), 19-34. [viewed 15 June 2007; not available 13 Nov 2011] http:/ / dx.doi.org/10.1080/17439880500515440

Kurt, S. (2009). Web2Quests: Updating a popular web-based inquiry-orientated activity. Educational Technology, 49(5), 35-37. [verified 13 Nov 2011]

http: / / citeseerx.ist.psu.edu / viewdoc/ download?doi=10.1.1.164.1887\&rep=rep1\&type=pdf

Lamb, A, Smith, N. \& Johnson, L. (1997). Wondering, wiggling, and weaving: A new model for project- and community-based learning on the web. Learning and Leading with Technology, 24(7), 6-13.

Lehrer, R. (1993). Authors of knowledge: Patterns of hypermedia design. In S. P. LaJoie \& S. J. Derry (Eds.), Computers as cognitive tools (pp. 197-227). Hillsdale, NJ: Erlbaum.

Lehrer, R., Erickson, J. \& Connell, T. (1994). Learning by designing hypermedia documents. In W. M. Reed, J. K. Burton \& M. Liu (Eds.), Multimedia and megachange: New roles for educational computing (pp. 227-254). New York, NY: Haworth Press. 
Liu, M. (1998). A study of engaging high-school students as multimedia designers in a cognitive apprenticeship-style learning environment. Computers in Human Behavior, 14(3), 387-415. http: / / dx.doi.org/10.1016/S0747-5632(98)00008-9

Liu, M. \& Hsiao, Y.-P. (2002). Middle school students as multimedia designers: A project-based learning approach. (To be published in 2003 in Interactive Learning Environments). [viewed 10 July 2002 at http: / / www.edb.utexas.edu/coe/depts/CI/it/liuhsiao-final.pdf, verified 13 Nov 2011 at http: / / www.eric.ed.gov/ERICWebPortal/ contentdelivery/servlet/ERIC Servlet?accno=ED462936]

Liu, M. (2003). Enhancing learners' cognitive skills through multimedia design. Interactive Learning Environments, 11(1), 23-39. http: / / dx.doi.org/10.1076/ilee.11.1.23.13686

Malone, T. W. \& Lepper, M. R. (1987). Making learning fun: A taxonomy of intrinsic motivations for learning. In R. E. Snow \& M. J. Farr (Eds.), Aptitude, learning, and instruction III. Cognitive and affective process analyses (pp. 223-253). Hillsdale, NJ: Lawrence Erlbaum.

McLoughlin, C. \& Lee, M. J. W. (2010). Personalised and self regulated learning in the Web 2.0 era: International exemplars of innovative pedagogy using social software. Australasian Journal of Educational Technology, 26(1), 28-43.

http:/ / www.ascilite.org.au/ajet/ajet26/mcloughlin.html

McGrath, D., Cumaranatunge, C., Ji, M., Chen, H., Broce, W. \& Wright, K. (1997). Multimedia science projects: Seven case studies. Journal of Research in Computing in Education, 30(1), 18-37.

McMahon, M. (1997). Social constructivism and the World Wide Web - A paradigm for learning. In What works and why. Proceedings ASCILITE Perth 1997.

http:/ / www.ascilite.org.au/conferences / perth97/ papers/Mcmahon/Mcmahon.html

Mlitwa, N. B. W. \& Nonyane, J. N. (2008). The status of ICT access and use in South African schools: Comparing the rural and urban schools in the Mpumalanga Province. [viewed 12 Jan 2011] http: / / emerge2008.net/ access / content/group/emerge2008/PresentationFiles / Mlitwa/Access_in_Schools.pdf

Morrison, G. R. \& Lowther, D. L. (2002). Integrating computer technology into the classroom. 2nd edition. Upper Saddle River, NJ: Merrill/Prentice Hall.

Perkins, D. N. (1986). Knowledge as design. Hillsdale, NJ: Erlbaum.

Rechtfertig, M.A. (2002). Online Learning Module: Internet Cyberhunts, Dixie School District Staff Development Day, January 16, 2002. [viewed 25 Feb 2008, verified 13 Nov 2011] http: / / dixiesd.marin.k12.ca.us/dixieschool/Classrooms / Rechtfertig/Cyberhunts /

SEAMEO (2010). Report: Status of ICT integration in education in Southeast Asian countries. Bangkok: SEAMEO, 2010. http:/ / www.seameo.org/images/stories/Publications / Project_ Reports /SEAMEO_ICT-Integration-Education2010.pdf

Schweizer, H. \& Kussow, B. (2007). WebQuests: Tools for differentiation. Gifted Child Today, 30(1), 29-35. http:/ / dx.doi.org/10.4219/gct-2007-19

Scutter, S., Stupans, I., Sawyer, T. \& King, S. (2010). How do students use podcasts to support learning? Australasian Journal of Educational Technology, 26(2), 180-191. http:/ / www.ascilite.org.au/ajet/ajet26/scutter.html

Slayden, B. (2000). Scavenger hunt for knowledge. [viewed 18 Jun 2007, verified 13 Nov 2011] http:/ / www.suite101.com/article.cfm/english_education_k12/33709 
Stager, G. (2005). Towards a pedagogy of online constructionist learning. Paper presented at the 2005 World Conference on Computers in Education. Stellenbosch, South Africa. [viewed 15 Jun 2009, verified 13 Nov 2011] http:/ / www.stager.org/articles/onlineconstructionism.pdf

Stubbé, H. E. \& Theunissen, N. C. M. (2008). Self-directed adult learning in a ubiquitous learning environment: A meta-review. In M. Kalz, R. Koper, V. Hornung-Pr\&\#228;hauser \& M. Luckmann (Eds), Proceedings of the First Workshop on Technology Support for Self-Organized Learners (pp. 5-28). Aachen, Germany: RWTH Aachen University.

Turner, S. V. \& Dipinto, V. M. (1992). Students as hypermedia authors: Themes emerging from a qualitative study. Journal of Research in Computing in Education, 25(2), 197-194.

Turner, S. V., \& Dipinto, V. M. (1997). Peer Collaboration in a Hypermedia Learning Environment. Journal of Research in Computing in Education, 29(4), 392-402.

Webster, J., Trevino, L. K. \& Ryan, L. (1993). The dimensionality and correlates of flow in human-computer interactions. Computers in Human Behavior, 9(4), 411-426. http: / / dx.doi.org/10.1016/0747-5632(93)90032-N

Wittstock, M., \& Barrantes, D. (2006). Constructionist learning, Piaget's constructivism and Papert's constructionism: Convergences and differences in kids learning field. [viewed 14 Jun 2009; not found 13 Nov 2011] http:/ / www.informatik.unibremen.de/ emming/mdm_final.pdf

Wong, A. F. L., Quek, C. L., Divaharan, S., Liu, W., Peer, J. \& Williams, M. D. (2006). Singapore students' and teachers' perceptions of computer-supported project work classroom learning environments. Journal of Research on Technology in Education, 38(4), 449-479. [verified 13 Nov 2011] http: / / business.highbeam.com/619/ article-1G1-147248807/ singapore-students-andteachers-perceptions-computersupported

Yildirim, Z. (2005). Hypermedia as a cognitive tool: Student teachers' experiences in learning by doing. Educational Technology and Society, 8(2), 107-117. http: / / www.ifets.info/journals/8_2/10.pdf

Authors: Dr André du Plessis is a lecturer in ICT and Primary School Mathematics Education at the Nelson Mandela Metropolitan University, PO Box 77000, Port Elizabeth 6031, South Africa. Andre's research interests are ICT in education, especially developing strategies for the South African context as well as assisting disadvantaged schools with ICT implementation. Email: andre.duplessis@nmmu.ac.za

Dr Paul Webb is a Professor of Science Education and Director of the Centre for Educational Research, Technology and Innovation at the Nelson Mandela Metropolitan University, Port Elizabeth, South Africa. Paul's research interests are the promotion of scientific literacy in schools via inquiry, reading, writing, discussion, argumentation and using technology. Email: paul.webb@nmmu.ac.za

Please cite as: Du Plessis, A. \& Webb, P. (2011). An extended Cyberhunts strategy: Learner centred learning-by-design. Australasian Journal of Educational Technology, 27(7), 1190-1207. http: / / www.ascilite.org.au/ajet/ ajet27 / duplessis.html 